\section{Propagation Daily Light Integral and Root-Zone Temperature Influence Rooting of Single-internode Pennisetum $\times$ advena Culm Cuttings}

\author{
W. Garrett Owen' ${ }^{1}$ and Roberto G. Lopez ${ }^{1}$ \\ Department of Horticulture, Michigan State University, 1066 Bogue Street, \\ East Lansing, MI 48824
}

Additional index words. basal heating, DLI, medium temperature, purple fountain grass, supplemental lighting

\begin{abstract}
Crown division, tissue culture, and culm cuttings are methods for propagating purple fountain grass [Pennisetum $\times$ advena Wipff and Veldkamp (formerly known as Pennisetum setaceum Forsk. Chiov. 'Rubrum')]. However, propagation by culm cuttings is becoming an economically attractive method for quick liner production. Our objective was to quantify the impact of propagation daily light integral (PDLI) and root-zone temperature (RZT) on root and culm development of single-internode purple fountain grass culm cuttings. Before insertion into the rooting substrate, cuttings were treated with a basal rooting hormone solution containing $1000 \mathrm{mg} \cdot \mathrm{L}^{-1}$ indole-3-butyric acid (IBA) $+500 \mathrm{mg} \cdot \mathrm{L}^{-1} 1$-naphthaleneacetic acid (NAA). The cuttings were placed in a glassglazed greenhouse with an air temperature of $23^{\circ} \mathrm{C}$ and benches with RZT set points of $21,23,25$, or $27^{\circ} \mathrm{C}$. PDLIs of 4 and $10 \mathrm{~mol} \cdot \mathrm{m}^{-2} \cdot \mathrm{d}^{-1}$ (Expt. 1) or 8 and $16 \mathrm{~mol} \cdot \mathrm{m}^{-2} \cdot \mathrm{d}^{-1}$ (Expt. 2) were provided. After $28 \mathrm{~d}$, culm and root densities (number) increased as the RZT increased from 21 to $27^{\circ} \mathrm{C}$, regardless of PDLI during Expt. 1. Compared with 4 $\mathrm{mol} \cdot \mathrm{m}^{-2} \cdot \mathrm{d}^{-1}$, a PDLI of $10 \mathrm{~mol} \cdot \mathrm{m}^{-2} \cdot \mathrm{d}^{-1}$ generally resulted in the greatest root biomass accumulation. For example, as PDLI increased from 4 to $10 \mathrm{~mol} \cdot \mathrm{m}^{-2} \cdot \mathrm{d}^{-1}$, root dry mass increased by $105 \%, 152 \%$, and $183 \%$ at RZTs of 21,25 , and $27^{\circ} \mathrm{C}$, respectively. In Expt. 2, as the RZT increased from 21 to $23{ }^{\circ} \mathrm{C}$, root dry mass increased by $70 \%$ under a PDLI of $8 \mathrm{~mol} \cdot \mathrm{m}^{-2} \cdot \mathrm{d}^{-1}$. However, root dry mass was similar among all RZTs under a PDLI of $16 \mathrm{~mol} \cdot \mathrm{m}^{-2} \cdot \mathrm{d}^{-1}$. Our results indicate that single-internode culm cuttings of purple fountain grass can be most efficiently propagated under PDLIs of $8-10 \mathrm{~mol} \cdot \mathrm{m}^{-2} \cdot \mathrm{d}^{-1}$ together with RZT set points of 23 to $25^{\circ} \mathrm{C}$ for quick liner production.
\end{abstract}

The U.S. commercial wholesale value of ornamental grasses increased by $22 \%$ from 2009 to 2014 (U.S. Department of Agriculture, 2010, 2015). Most of the ornamental grasses commercially produced are perennials. Purple fountain grass $[P$. ×advena Wipff and Veldkamp (formerly known as $P$. setaceum Forsk. Chiov. 'Rubrum')] is a popular ornamental grass grown commercially as a horticultural annual in the United States (Bailey, 1949; Drake, 1999), although it is

Received for publication 31 Aug. 2017. Accepted for publication 6 Dec. 2017

We gratefully acknowledge Brian E. Jackson, William C. Fonteno, and Laura Kaderabek for substrate analysis, and Judy Santini for experimental design and statistical consultation. We thank Pleasant View Gardens, Inc. for plant material; Sun Gro Horticulture for substrate; Ludvig Svensson US, Inc. for shadecloth; J.R. Peters, Inc. for fertilizer; and the Fred C. Gloeckner Foundation, Inc., Pleasant View Gardens, Inc., and Four Star Greenhouses, Inc. for financial support. The use of trade names in this publication does not imply endorsement by Michigan State University of products named nor criticism of similar ones not mentioned.

${ }^{1}$ Corresponding authors. E-mail: rglopez@msu. edu orwgowen@msu.edu.
5 to $10 \mathrm{~mol} \cdot \mathrm{m}^{-2} \cdot \mathrm{d}^{-1}$. These low-light conditions increase rooting time, do not maximize root production, and result in low-quality liners. For example, crop time from division to a marketable 50-cell liner tray $(106.5-\mathrm{mL}$ individual cell volume) from fall to early winter, late winter to early spring, or spring to summer is 12,10 , and 8 weeks, respectively (M. Goyette, personal communication). Therefore, reduced crop time from spring to summer is consistent with previous research indicating that increased DLI during root development increases rooting, biomass accumulation, and quality of annual bedding plant cuttings (Lopez and Runkle, 2008).

Numerous studies have evaluated effects of PDLI (Currey et al., 2012; Enfield, 2002; Hutchinson et al., 2012; Lopez and Runkle, 2008), and, to a lesser extent, RZT (Iapichino and Bertolino, 2009; Wilkerson et al., 2005) on growth, morphology, and quality of vegetatively propagated annual bedding plants and herbaceous perennials during rhizogenesis of cuttings. Daily light integral during propagation influences photosynthesis, respiration, stomatal conductance, leaf, stem, and root mass ratios, leaf area ratio, specific leaf area, chlorophyll content, and carbohydrate status of cuttings (Currey and Lopez, 2015). During propagation, cuttings require a minimum DLI to provide a supply of carbohydrates for callus and adventitious root initiation and development (Geiss et al., 2009; Lopez and Runkle, 2008).

In addition to PDLI, temperature during propagation generally influences many physiological processes, including photosynthesis, respiration, transpiration, and root and shoot development (Blanchard et al., 2006). Temperature can potentially influence adventitious root capacity in many aspects, such as by influencing water and nutrient uptake and metabolism, thereby promoting or inhibiting enzymatic action (Geiss et al., 2009). Specifically, RZT is a major factor controlling plant growth and development, thus influencing cell division and expansion, and the capacity of plants to construct root tissue as well as root-tissue morphology and function (Pregitzer et al., 2000). Previous investigations have shown RZT to be critical for root initiation in garden mum (Chrysanthemum morifolium L. 'Bright Golden Anne' and 'KiAmagahara') (Dykeman, 1976; Takahashi et al., 1981) and poinsettia (Euphorbia pulcherrima Willd. Ex Klotzsch 'Freedom Dark Red') (Wilkerson et al., 2005). Studies indicate that increasing RZT hastens the time to visible root formation and increases root density per cutting up to a speciesdependent optimum temperature $\left(T_{\mathrm{o}}\right)$, above which increasing temperature has a deleterious impact on rooting $\left(T_{\max }\right)$ (Ochoa et al., 2004; Wilkerson et al., 2005). Suboptimal temperatures may inhibit or limit adventitious root formation because cuttings do not metabolize at a rate sufficient for optimum rooting (Preece, 1993).

Previous cutting propagation studies with ornamental grasses (Cunliffe et al., 2001; 
Meyer and Hong, 2011) focused on rooting substrate composition, IBA application, and rooting success at different node positions. To our knowledge, no studies have been published on the effects of PDLI and RZT on rhizogenesis of vegetative single-internode purple fountain grass culm cuttings. Therefore, our objectives were to determine the effects of PDLI and RZT on rhizogenesis, biomass accumulation, and quality of singleinternode culm cuttings.

\section{Material and Methods}

Stock plant material, management, and culture. On 6 Feb. 2014, purple fountain grass liners in 50-cell deep liner trays (106.5-mL individual cell volume; East Jordan Plastics, East Jordan, MI) were received from a commercial greenhouse supplier (Pleasant View Gardens, Inc., Loudon, NH). Individual liners (average 6.7-cm tall) were transplanted into $12.7-\mathrm{cm}(885 \mathrm{~mL})$ plastic containers (ITML Horticultural Products, Middlefield, $\mathrm{OH})$ filled with a commercial soilless peatbased substrate comprising (by volume) $65 \%$ peat, $20 \%$ perlite, and $15 \%$ vermiculite, plus dolomitic limestone, wetting agent, and a starter nutrient charge with gypsum (Fafard 2; Sun Gro Horticulture, Agawam, MA). On 22 Mar., stock plants were transplanted and grown in 11.4-L plastic containers (1200 classic; Nursery Supplies, Inc., Chambersburg, PA) filled with a commercial soilless bark-based substrate comprising (by volume) $60 \%$ composted pine bark, $25 \%$ peat, $8 \%$ perlite, and 7\% vermiculite, plus dolomitic limestone, wetting agent, and a starter nutrient charge with gypsum (Fafard 52; Sun Gro Horticulture). The plants were irrigated as necessary with acidified water supplemented with water-soluble fertilizer [3:1 mixture of $15 \mathrm{~N}-2.2 \mathrm{P}-12.5 \mathrm{~K}$ and $21 \mathrm{~N}-2.2 \mathrm{P}-16.6 \mathrm{~K}$; (Everris NA Inc., Marysville, $\mathrm{OH}$ )] to provide the following $\left(\mathrm{mg} \cdot \mathrm{L}^{-1}\right): 200$ nitrogen $(\mathrm{N}), 26$ phosphorous $(\mathrm{P}), 163$ potassium $(\mathrm{K})$, 50 calcium $(\mathrm{Ca}), 20$ magnesium $(\mathrm{Mg}), 1.0$ iron (Fe), 0.5 manganese $(\mathrm{Mn})$ and zinc $(\mathrm{Zn})$, 0.24 copper $(\mathrm{Cu})$ and boron $(\mathrm{B})$, and 0.1 molybdenum (Mo). Irrigation water was injected with 93\% sulfuric acid (Brenntag, Reading, PA) at $0.08 \mathrm{mg} \cdot \mathrm{L}^{-1}$, which reduced alkalinity from 400 to $100 \mathrm{mg} \cdot \mathrm{L}^{-1}$ calcium carbonate $\left(\mathrm{CaCO}_{3}\right)$ and $\mathrm{pH}$ from 7.4 to a range of 5.8-6.2. To promote tillering, the stock plants were mechanically pruned on 25 June, 16 Oct., and again on 1 Dec.

The stock plants were spaced on $1.5-\mathrm{m}^{2}$ centers and grown in a glass-glazed greenhouse with exhaust fan, evaporative-pad cooling, radiant hot-water heating, and retractable shade curtains controlled by an environmental control system (Maximizer Precision 10; Priva North America, Vineland Station, ON, Canada). Greenhouse day and night air temperature set points were maintained at a constant $23^{\circ} \mathrm{C}$. The photoperiod was $16 \mathrm{~h}(0600$ to $2200 \mathrm{HR})$ consisting of natural daylengths with day-extension lighting from high-pressure sodium lamps [(HPS); e-system HID; PARSource, Petaluma, CA] that delivered a supplemental photosynthetic photon flux $(P P F)$ of $160.3 \pm 2.6 \mu \mathrm{mol} \cdot \mathrm{m}^{-2} \cdot \mathrm{s}^{-1}$ at plant height [as measured with a quantum sensor (LI-250A light meter; LI-COR Biosciences, Lincoln, NE)] when outdoor irradiance was less than $300 \mu \mathrm{mol} \cdot \mathrm{m}^{-2} \cdot \mathrm{s}^{-1}$. Retractable woven shade curtains (OLS 50; Ludvig Svensson US, Inc., Charlotte, NC) were retracted when the outdoor light intensity exceeded $\approx 1000 \mu \mathrm{mol} \cdot \mathrm{m}^{-2} \cdot \mathrm{s}^{-1}$ throughout stock plant culture. Greenhouse air temperature measurements were recorded by an aspirated PRIVA resistance-based sensor (Priva North America). Quantum sensor measurements were recorded every $30 \mathrm{~s}$, and the average reading of each sensor was logged every $15 \mathrm{~min}$ by a data logger (Model CR1000; Campbell Scientific, Inc., Logan, $\mathrm{UT}$ ). The average (mean $\pm \mathrm{SD}$ ) air temperature, DLI, and relative humidity $(\mathrm{RH})$ for stock plants were $22.3 \pm 3.1{ }^{\circ} \mathrm{C}, 16.3 \pm 6.3$ $\mathrm{mol} \cdot \mathrm{m}^{-2} \cdot \mathrm{d}^{-1}$, and $64.6 \% \pm 18.6 \%$, respectively.

Propagation material and culture. On 12 and 13 Feb. (Expt. 1) and on 26 and 27 Mar. (Expt. 2), culmed vegetative tillers with four nodes were excised from stock plants above the node most proximal to the crown (node position 1 ), thereby avoiding any preformed adventitious cluster or aerial roots. Harvested tillers with three nodes were excised $1 \mathrm{~cm}$ below and above the second to fourth nodes (node positions 2-4), sequentially distal to the first node, resulting in 400 uniform unrooted single-internode culm cuttings with two developed leaf blades and a length of $\approx 18 \mathrm{~cm}$.

The basal end of each culm cutting was dipped for $3 \mathrm{~s}$ into a rooting hormone solution containing $4920.4 \mathrm{~mm}\left(1000 \mathrm{mg} \cdot \mathrm{L}^{-1}\right) \mathrm{IBA}+$ $2685.2 \mathrm{~mm}$ (500 mg.L $\mathrm{L}^{-1}$ ) NAA (Dip'N Grow Liquid Rooting Concentrate; Dip'N Grow, Clackamas, OR) and stuck individually into a 50-cell liner tray $(70-\mathrm{mL}$ individual cell volume; T.O. Plastics, Clearwater, MN) filled with a propagation substrate comprising (by volume) $50 \%$ commercial soilless substrate (Fafard 2; Sun Gro Horticulture) and 50\% coarse perlite (Strong-Lite Coarse Perlite; Sun Gro Horticulture). Propagation substrate's physical properties were determined using three representative samples and analyzed according to the North Carolina State University Porometer Procedure (Fonteno et al., 1995). The physical properties of the propagation substrate were (by vol.) $19.6 \% \pm$ $0.4 \%$ air space, $82.1 \% \pm 0.5 \%$ total porosity, $62.5 \% \pm 0.2 \%$ container capacity, and 0.11 $\mathrm{g} \cdot \mathrm{cm}^{-3}$ bulk density. To avoid water accumulation on leaf blades during mist, the cuttings were sprayed to runoff with a solution containing $300 \mathrm{mg} \cdot \mathrm{L}^{-1}$ nonionic surfactant (CapSil; Aquatrols, Paulsboro, NJ).

Propagation environment. The cuttings were placed in a glass-glazed greenhouse on one of two propagation benches with rootzone heating and under PDLI treatments. Each propagation bench was insulated with cellofoam-expanded polystyrene boards faced with reflective foil $(1.2 \mathrm{~m} \times 2.4 \mathrm{~m} \times 2.3 \mathrm{~cm})$. A closed-loop bench-top root-zone heating system was installed with microtubing that circulated hot water $\left(49^{\circ} \mathrm{C}\right)$ across the bench (Biotherm ${ }^{\circledR}$ Benchwarmer Kit; TrueLeaf Technologies, Petaluma, CA), providing two root-zone heating environments on each bench. To evenly distribute heat across the bench top, the microtubing was covered with 2-mm-thick galvanized sheet metal. To prevent heat loss and moisture accumulation, high-temperature aluminum foil tape $(6.3 \mathrm{~cm}$ $\times 9.1 \mathrm{~m}$ ) was used to adhere the sheet metal to each bench. In addition, benches were covered with a 4-mil black construction film ( $3 \mathrm{~m}$ $\times 30.5 \mathrm{~m}$ roll). Root-zone heating environments were individually programmed to temperature set points of $21,23,25$, or $27{ }^{\circ} \mathrm{C}$ and were controlled by a substrate thermistor (Biotherm ${ }^{\circledR}$ Benchwarmer Kit; TrueLeaf Technologies).

During Expt. 1, the cuttings were placed under shadecloth providing $\approx 56 \%$ shade (Solaro 5620 O-R-FR; Ludvig Svensson US, Inc.) or no shade $(\approx 0 \%)$ under ambient daylight supplemented with a $P P F$ of $57.6 \pm$ 8.1 or $120.4 \pm 5.8 \mu \mathrm{mol} \cdot \mathrm{m}^{-2} \cdot \mathrm{s}^{-1}$ at cutting height [as measured with a quantum sensor (LI-COR Biosciences)], respectively, delivered from HPS lamps from 0600 to $2200 \mathrm{HR}$ (16-h photoperiod) daily. Except where indicated, procedures for Expt. 2 were the same as described for Expt. 1. During Expt. 2, the cuttings were placed under shadecloth providing 30\% shade (OLS 30; Ludvig Svensson US, Inc.) or no shade under ambient daylight supplemented with a $P P F$ of $88.3 \pm 5.3$ or $121.2 \pm 4.7 \mu \mathrm{mol} \cdot \mathrm{m}^{-2} \cdot \mathrm{s}^{-1}$ at cutting height, respectively, delivered from HPS lamps. From 17 Feb. to 13 Mar. (Expt. 1) and from 26 Mar. to 13 Apr. (Expt. 2), woven shade curtains (OLS 50; Ludvig Svensson US, Inc.) were retracted when the outdoor light intensity reached 1000 and $700 \mu \mathrm{mol} \cdot \mathrm{m}^{-2} \cdot \mathrm{s}^{-1}$, respectively.

Beginning at placement of cuttings under PDLI and RZT treatments, mist consisting of reverse osmosis (RO) water was controlled (Nova 1626ET mist controller; Phytotronics, Inc., Earth City, MO) and applied for $6 \mathrm{~s}$ every $10 \mathrm{~min}$ beginning and ending $2 \mathrm{~h}$ before and after the photoperiod. After $1 \mathrm{~d}$, misting frequency was reduced to $4 \mathrm{~s}$ every $20 \mathrm{~min}$, and after $2 \mathrm{~d}$, misting frequency was adjusted for each PDLI and RZT treatment. At $7 \mathrm{~d}$, mist was adjusted to begin and end $1 \mathrm{~h}$ before and after the photoperiod and was discontinued at $10 \mathrm{~d}$. Beginning at $10 \mathrm{~d}$, the cuttings were over-head irrigated once daily with RO water supplemented with a water-soluble fertilizer (Jack's LX 16N-0.94P-12.3K Plug Formula for High Alkalinity Water; J.R. Peters, Inc., Allentown, PA) and micronutrient supplement (M.O.S.T.; J.R. Peters, Inc.) providing (in $\mathrm{mg} \cdot \mathrm{L}^{-1}$ ): $60 \mathrm{~N}, 5 \mathrm{P}, 39 \mathrm{~K}$, $9 \mathrm{Ca}, 5.1 \mathrm{Mg}, 13.0 \mathrm{~S}, 1.4 \mathrm{~B}, 2.325 \mathrm{Cu}, 8.0 \mathrm{Fe}$, $8.125 \mathrm{Mn}, 0.425 \mathrm{Mo}$, and 4.625 Zn.

Precision thermistors measured and recorded canopy air temperatures under mist [fan-aspirated under solar radiation shields (ST-110; Apogee Instruments, Inc., Logan, UT)] and propagation substrate (ST-100; Apogee Instruments, Inc.) temperatures. 
Quantum sensors (LI-190SL; LI-COR Biosciences) measured $P P F$ under each PDLI treatment. Measurements were recorded every $30 \mathrm{~s}$ and the average of each sensor was logged every 15 min by a data logger (Model CR1000; Campbell Scientific, Inc.). Greenhouse air temperature and $\mathrm{RH}$ set points were $23{ }^{\circ} \mathrm{C}$ and $80 \%$, respectively. Environmental data collected during Expts. 1 and 2 are reported in Table 1.

Growth and morphological data and calculations. Data were collected $28 \mathrm{~d}$ after the cuttings were placed in each propagation environment. The cuttings were removed from propagation trays and the propagation substrate was gently rinsed off the roots. The number of culms $\geq 5-\mathrm{mm}$ in length that developed during rooting were counted to determine culm density for each cutting. The number of roots $\geq 5-\mathrm{mm}$ in length was counted to determine root density and the length of the longest root was measured and recorded for each cutting. Roots were excised from the single-internode culm cutting and roots and culms were dried separately in an oven at $70{ }^{\circ} \mathrm{C}$.

Roots and culms were weighed to determine root dry mass and culm dry mass, respectively. Data calculated for each singleinternode culm cutting included total plant dry mass (root dry mass + culm dry mass), root-to-culm dry mass ratio (root dry mass/ culm dry mass), culm mass ratio (culm dry mass/total dry mass), and root mass ratio (root dry mass/total dry mass). In addition, the percentage of culm cuttings rooted (which is the number of cuttings rooted/number of cuttings stuck) was also calculated.

Experimental design and statistical analyses. The experiments used a randomized block design in a factorial arrangement. For Expts. 1 and 2, the factors were PDLI (two levels) and RZT (four levels). The cuttings were randomly assigned to each PDLI and RZT treatment, and PDLI treatments were randomized across propagation benches within the greenhouse. Each experiment was replicated across propagation benches with 10 samples (individual cuttings) per PDLI $\times$ RZT. No significant differences occurred between replications; therefore, data were pooled. Data were analyzed using SAS (version 9.2; SAS Institute, Cary, NC) mixed model procedure (PROC MIXED) for analysis of variance and means were separated by Duncan's least significant difference test at $P \leq 0.05$.

\section{Results}

Expt. 1. After $28 \mathrm{~d}$ of propagation under a PDLI of $10 \mathrm{~mol} \cdot \mathrm{m}^{-2} \cdot \mathrm{d}^{-1}$, rooting percentage of cuttings was similar among all RZT set points (Table 2). Under a PDLI of $4 \mathrm{~mol} \cdot \mathrm{m}^{-2} \cdot \mathrm{d}^{-1}$, rooting percentage increased by $73 \%$ as RZT set points increased from 21 to $25{ }^{\circ} \mathrm{C}$. Rooting percentage increased by $55 \%$ as the PDLI increased from 4 to $10 \mathrm{~mol} \cdot \mathrm{m}^{-2} \cdot \mathrm{d}^{-1}$ at an RZT set point of $21^{\circ} \mathrm{C}$.

The number of culms developed in cuttings under PDLIs of 4 and $10 \mathrm{~mol} \cdot \mathrm{m}^{-2} \cdot \mathrm{d}^{-1}$ increased by $180 \%$ and $95 \%$, respectively, as RZT set points increased from 21 to $27{ }^{\circ} \mathrm{C}$ (Table 2). In addition, at an RZT set point $23^{\circ} \mathrm{C}$, a PDLI of $10 \mathrm{~mol} \cdot \mathrm{m}^{-2} \cdot \mathrm{d}^{-1}$ resulted in $43 \%$ more culms than at a PDLI of $4 \mathrm{~mol} \cdot \mathrm{m}^{-2} \cdot \mathrm{d}^{-1}$. In general, average root density per singleinternode culm cutting increased as RZT increased from 21 to $27^{\circ} \mathrm{C}$ under each PDLI. However, under a PDLI of $10 \mathrm{~mol} \cdot \mathrm{m}^{-2} \cdot \mathrm{d}^{-1}$, single-internode culm cuttings developed more roots at a lower RZT $\left(23^{\circ} \mathrm{C}\right)$, compared with a PDLI of $4 \mathrm{~mol} \cdot \mathrm{m}^{-2} \cdot \mathrm{d}^{-1}$, which required a higher RZT $\left(25^{\circ} \mathrm{C}\right)$ for similar root development. Average root length per singleinternode culm cutting generally exhibited an inverse trend to root number. As RZT increased, root length was shorter under each PDLI. For example, RZT set points of 23, 25, and $27{ }^{\circ} \mathrm{C}$ resulted in $11 \%, 22 \%$, and $28 \%$ shorter roots, respectively, compared with an RZT of $21^{\circ} \mathrm{C}$ under a PDLI of $10 \mathrm{~mol} \cdot \mathrm{m}^{-2} \cdot \mathrm{d}^{-1}$.

Under a PDLI of 4 and $10 \mathrm{~mol} \cdot \mathrm{m}^{-2} \cdot \mathrm{d}^{-1}$, culm dry mass increased by $42 \%$ and $33 \%$, respectively, as RZT increased from 21 to $25^{\circ} \mathrm{C}$ (Table 2). Root dry mass increased by $140 \%$ as RZT increased from 21 to $23{ }^{\circ} \mathrm{C}$ under a PDLI of $4 \mathrm{~mol} \cdot \mathrm{m}^{-2} \cdot \mathrm{d}^{-1}$, whereas under a PDLI of $10 \mathrm{~mol} \cdot \mathrm{m}^{-2} \cdot \mathrm{d}^{-1}$, root dry mass exhibited a $66 \%$ increase as RZT increased from 21 to $25{ }^{\circ} \mathrm{C}$. Compared with $4 \mathrm{~mol} \cdot \mathrm{m}^{-2} \cdot \mathrm{d}^{-1}$, a PDLI of $10 \mathrm{~mol} \cdot \mathrm{m}^{-2} \cdot \mathrm{d}^{-1}$ generally resulted in the greatest root biomass accumulation. For example, as PDLI increased from 4 to $10 \mathrm{~mol} \cdot \mathrm{m}^{-2} \cdot \mathrm{d}^{-1}$, root dry mass increased by $152 \%$ and $183 \%$ at RZTs of 25 and $27{ }^{\circ} \mathrm{C}$, respectively. In addition, as RZT increased from 21 to $27{ }^{\circ} \mathrm{C}$, total dry mass increased by $58 \%$ and $57 \%$ under PDLIs of 4 and $10 \mathrm{~mol} \cdot \mathrm{m}^{-2} \cdot \mathrm{d}^{-1}$, respectively.

Root-to-culm dry mass ratio, and culm and root mass ratios were significantly influenced by PDLI and RZT. Under PDLIs of 4 and $10 \mathrm{~mol} \cdot \mathrm{m}^{-2} \cdot \mathrm{d}^{-1}$, root-to-culm dry mass ratio increased from 0.05 to 0.10 and 0.08 to 0.10 as RZT increased from 21 to $23{ }^{\circ} \mathrm{C}$ and 21 to $25{ }^{\circ} \mathrm{C}$, respectively (Table 2). Root mass ratio followed a similar trend. The combination of RZT of $23{ }^{\circ} \mathrm{C}$ with a PDLI of $4 \mathrm{~mol} \cdot \mathrm{m}^{-2} \cdot \mathrm{d}^{-1}$ and RZT of $25^{\circ} \mathrm{C}$ with a PDLI of $10 \mathrm{~mol} \cdot \mathrm{m}^{-2} \cdot \mathrm{d}^{-1}$ resulted in significantly higher root-to-culm dry mass ratio and root mass ratio, respectively. However, RZT set points of 21,25 , and $27{ }^{\circ} \mathrm{C}$ under a PDLI of $4 \mathrm{~mol} \cdot \mathrm{m}^{-2} \cdot \mathrm{d}^{-1}$ and an RZT of $27{ }^{\circ} \mathrm{C}$ under a PDLI of $10 \mathrm{~mol} \cdot \mathrm{m}^{-2} \cdot \mathrm{d}^{-1}$ resulted in the greatest culm mass ratio. For example, culm mass ratio under PDLI of $4 \mathrm{~mol} \cdot \mathrm{m}^{-2} \cdot \mathrm{d}^{-1}$ increased by $6 \%$ as RZT increased from 23 to $25{ }^{\circ} \mathrm{C}$.

Expt. 2. The percentage of rooted cuttings after $28 \mathrm{~d}$ of propagation under a PDLI of 16 $\mathrm{mol} \cdot \mathrm{m}^{-2} \cdot \mathrm{d}^{-1}$ was similar among all RZT set points (Table 3 ). Under a PDLI of $8 \mathrm{~mol} \cdot \mathrm{m}^{-2} \cdot \mathrm{d}^{-1}$, rooting percentage increased by $100 \%$ with

Table 1. Average photosynthetic propagation daily light integrals (PDLIs), substrate, canopy, air temperatures, and relative humidity (RH) during $28 \mathrm{~d}$ of propagation of single-internode culm cuttings of purple fountain grass [Pennisetum $\times$ advena Wipff and Veldkamp (formerly known as Pennisetum setaceum Forsk. Chiov. 'Rubrum')]. Cuttings were propagated under $56 \%$ or $0 \%$ (Expt. 1) or $30 \%$ or $0 \%$ (Expt. 2) shade under ambient daylight supplemented with 57.6 \pm 8.1 or $120.4 \pm 5.8 \mu \mathrm{mol} \cdot \mathrm{m}^{-2} \cdot \mathrm{s}^{-1}$ or $88.3 \pm 5.3$ or $121.2 \pm 4.7 \mu \mathrm{mol} \cdot \mathrm{m}^{-2} \cdot \mathrm{s}^{-1}$, respectively, delivered from high-pressure sodium lamps from 0600 to $2200 \mathrm{HR}$. Root-zone temperature set points were $21,23,25$, and $27^{\circ} \mathrm{C}$.

\begin{tabular}{|c|c|c|c|c|c|c|}
\hline \multirow[b]{2}{*}{ Propagation dates } & \multirow[b]{2}{*}{ Shade $(\%)$} & \multirow[b]{2}{*}{ Photosynthetic PDLI $\left(\mathrm{mol} \cdot \mathrm{m}^{-2} \cdot \mathrm{d}^{-1}\right)$} & \multicolumn{3}{|c|}{ Propagation temp $\left({ }^{\circ} \mathrm{C}\right)$} & \multirow[b]{2}{*}{ RH (\%) } \\
\hline & & & Substrate & Canopy & Air & \\
\hline & & $4.4 \pm 0.5$ & $23.6 \pm 0.9$ & $22.3 \pm 0.8$ & & \\
\hline & & $4.4 \pm 0.7$ & $25.7 \pm 0.8$ & $24.1 \pm 1.4$ & & \\
\hline & 0 & $10.0 \pm 0.7$ & $21.0 \pm 1.6$ & $21.0 \pm 1.0$ & & \\
\hline & & $10.8 \pm 2.0$ & $23.7 \pm 0.8$ & $23.1 \pm 0.8$ & & \\
\hline \multirow[t]{6}{*}{ Expt. 2} & 30 & $8.0 \pm 2.4$ & $21.5 \pm 1.8$ & $22.2 \pm 1.1$ & $22.5 \pm 2.4$ & $74.3 \pm 16.9$ \\
\hline & & $8.0 \pm 2.9$ & $23.6 \pm 2.1$ & $21.0 \pm 1.5$ & & \\
\hline & & $8.0 \pm 3.6$ & $25.9 \pm 1.9$ & $22.9 \pm 1.7$ & & \\
\hline & & $8.1 \pm 3.0$ & $27.0 \pm 1.6$ & $22.2 \pm 2.2$ & & \\
\hline & 0 & $16.0 \pm 2.0$ & $21.7 \pm 1.9$ & $23.1 \pm 1.1$ & & \\
\hline & & $16.0 \pm 2.1$ & $23.8 \pm 2.7$ & $21.2 \pm 1.6$ & & \\
\hline
\end{tabular}


Table 2. Rooting percentage, average culm number, root density (number), root length, culm dry mass, root dry mass, total dry mass, root-to-culm dry mass ratio, culm mass ratio, and root mass ratio during root development of purple fountain grass [Pennisetum $\times$ advena Wipff and Veldkamp (formerly known as Pennisetum setaceum Forsk. Chiov. 'Rubrum')] single-internode culm cuttings. During Expt. 1, cuttings were rooted for $28 \mathrm{~d}$ under $56 \%$ or $0 \%$ shade under ambient daylight supplemented with $57.6 \pm$ 8.1 or $120.4 \pm 5.8 \mu \mathrm{mol} \cdot \mathrm{m}^{-2} \cdot \mathrm{s}^{-1}$, respectively, delivered from high-pressure sodium lamps from 0600 to $2200 \mathrm{HR}$ to achieve two photosynthetic propagation daily light integrals (PDLIs) of 4 and $10 \mathrm{~mol} \cdot \mathrm{m}^{-2} \cdot \mathrm{d}^{-1}$ and with root-zone temperature (RZT) set points of $21,23,25$, and $27^{\circ} \mathrm{C}$.

\begin{tabular}{|c|c|c|c|c|}
\hline \multirow[b]{2}{*}{ Photosynthetic } & \multicolumn{4}{|c|}{$\operatorname{RZT}\left({ }^{\circ} \mathrm{C}\right)$} \\
\hline & 21 & 23 & 25 & 27 \\
\hline PDLI $\left(\mathrm{mol} \cdot \mathrm{m}^{-2} \cdot \mathrm{d}^{-1}\right)$ & \multicolumn{4}{|c|}{ Rooting percentage $(\%)^{z}$} \\
\hline 4 & $55 \mathrm{~b}^{y} \mathrm{~B}^{\mathrm{x}}$ & $85 \mathrm{aAB}$ & $95 \mathrm{aA}$ & $90 \mathrm{aAB}$ \\
\hline 10 & $85 \mathrm{aA}$ & $90 \mathrm{aA}$ & $100 \mathrm{aA}$ & $100 \mathrm{aA}$ \\
\hline \multicolumn{5}{|l|}{ Significance } \\
\hline PDLI & *w & & & \\
\hline RZT & $*$ & & & \\
\hline \multirow[t]{2}{*}{ PDLI $\times$ RZT } & NS & & & \\
\hline & \multicolumn{4}{|c|}{ Culm number ${ }^{v}$} \\
\hline 4 & $3.0 \mathrm{bC}$ & $5.3 \mathrm{bB}$ & $6.1 \mathrm{aB}$ & $8.4 \mathrm{aA}$ \\
\hline 10 & $4.4 \mathrm{aB}$ & $7.6 \mathrm{aA}$ & $9.4 \mathrm{aA}$ & $8.6 \mathrm{aA}$ \\
\hline \multicolumn{5}{|l|}{ Significance } \\
\hline PDLI & $* * *$ & & & \\
\hline RZT & $* * *$ & & & \\
\hline \multirow{2}{*}{ PDLI $\times$ RZT } & * & & & \\
\hline & \multicolumn{4}{|c|}{ Root density (no. $)^{\mathrm{u}}$} \\
\hline 4 & $4.1 \mathrm{bB}$ & $5.7 \mathrm{bB}$ & $8.1 \mathrm{aA}$ & $10.2 \mathrm{aA}$ \\
\hline 10 & $6.3 \mathrm{aB}$ & $10.1 \mathrm{aA}$ & $10.8 \mathrm{aA}$ & $9.6 \mathrm{aA}$ \\
\hline \multicolumn{5}{|l|}{ Significance } \\
\hline PDLI & ** & & & \\
\hline RZT & $* * *$ & & & \\
\hline \multirow[t]{2}{*}{ PDLI $\times$ RZT } & $*$ & & & \\
\hline & \multicolumn{4}{|c|}{ Root length $(\mathrm{cm})^{\mathrm{t}}$} \\
\hline 4 & $22.9 \mathrm{aA}$ & $18.2 \mathrm{bB}$ & $17.8 \mathrm{aB}$ & $17.8 \mathrm{aB}$ \\
\hline 10 & $24.9 \mathrm{aA}$ & $22.2 \mathrm{aAB}$ & $19.3 \mathrm{aBC}$ & $18.0 \mathrm{aC}$ \\
\hline \multicolumn{5}{|l|}{ Significance } \\
\hline PDLI & $* * *$ & & & \\
\hline RZT & $* *$ & & & \\
\hline $\mathrm{PDLI} \times \mathrm{RZT}$ & NS & & & \\
\hline & & Culm & (mg) & \\
\hline 4 & $399 \mathrm{aB}$ & $446 \mathrm{bB}$ & $566 \mathrm{aA}$ & $639 \mathrm{aA}$ \\
\hline 10 & $462 \mathrm{aC}$ & $508 \mathrm{aBC}$ & $614 \mathrm{aA}$ & $722 \mathrm{aA}$ \\
\hline Significance & & & & \\
\hline PDLI & * & & & \\
\hline RZT & $* * *$ & & & \\
\hline $\mathrm{PDLI} \times \mathrm{RZT}$ & $* *$ & & & \\
\hline & & Root & (mg) & \\
\hline 4 & $20 \mathrm{bB}$ & $48 \mathrm{aA}$ & $27 \mathrm{bB}$ & $24 \mathrm{bB}$ \\
\hline 10 & $41 \mathrm{aB}$ & $47 \mathrm{aB}$ & $68 \mathrm{aA}$ & $68 \mathrm{aA}$ \\
\hline Significance & & & & \\
\hline PDLI & $* * *$ & & & \\
\hline RZT & $* * *$ & & & \\
\hline PDLI $\times$ RZT & NS & & & \\
\hline & & Total pla & iss (mg) & \\
\hline 4 & $419 \mathrm{aC}$ & 494 bBC & $593 \mathrm{bAB}$ & $663 \mathrm{aA}$ \\
\hline 10 & $503 \mathrm{aB}$ & $555 \mathrm{aB}$ & $682 \mathrm{aAB}$ & $790 \mathrm{aA}$ \\
\hline Significance & & & & \\
\hline PDLI & * & & & \\
\hline RZT & $* * *$ & & & \\
\hline $\mathrm{PDLI} \times \mathrm{RZT}$ & $*$ & & & \\
\hline & & Root-to-c & lass ratio & \\
\hline 4 & $0.05 \mathrm{bB}$ & $0.10 \mathrm{bA}$ & $0.05 \mathrm{bB}$ & $0.04 \mathrm{bB}$ \\
\hline 10 & $0.08 \mathrm{aB}$ & $0.08 \mathrm{aB}$ & $0.10 \mathrm{aA}$ & $0.04 \mathrm{aC}$ \\
\hline Significance & & & & \\
\hline PDLI & $* * *$ & & & \\
\hline RZT & $* * *$ & & & \\
\hline PDLI $\times$ RZT & NS & & & \\
\hline & & $\mathrm{Cul}$ & & \\
\hline 4 & $0.95 \mathrm{aA}$ & $0.90 \mathrm{aB}$ & $0.95 \mathrm{aA}$ & $0.96 \mathrm{aA}$ \\
\hline 10 & $0.92 \mathrm{bB}$ & $0.92 \mathrm{aB}$ & $0.90 \mathrm{bC}$ & $0.96 \mathrm{aA}$ \\
\hline Significance & & & & \\
\hline PDLI & $* * *$ & & & \\
\hline RZT & $* * *$ & & & \\
\hline $\mathrm{PDLI} \times \mathrm{RZT}$ & NS & & & \\
\hline & & Ro & & \\
\hline 4 & $0.05 \mathrm{bA}$ & $0.10 \mathrm{aA}$ & $0.05 \mathrm{bB}$ & $0.04 \mathrm{aB}$ \\
\hline 10 & $0.08 \mathrm{aB}$ & $0.08 \mathrm{bB}$ & $0.10 \mathrm{aA}$ & $0.04 \mathrm{aC}$ \\
\hline
\end{tabular}

(Continued on next page) increasing RZT set points from 21 to $23{ }^{\circ} \mathrm{C}$. Increasing PDLI from 8 to $16 \mathrm{~mol} \cdot \mathrm{m}^{-2} \cdot \mathrm{d}^{-1} \mathrm{did}$ not significantly influence the rooting percentage at RZT set points of 23 and $25^{\circ} \mathrm{C}$, respectively.

Culm number decreased by $49 \%$ as PDLI increased from 8 to $16 \mathrm{~mol} \cdot \mathrm{m}^{-2} \cdot \mathrm{d}^{-1}$ at an RZT set point of $23{ }^{\circ} \mathrm{C}$ (Table 3 ). Root density under a PDLI of $8 \mathrm{~mol} \cdot \mathrm{m}^{-2} \cdot \mathrm{d}^{-1}$ was similar among all RZTs. However, under a PDLI of $16 \mathrm{~mol} \cdot \mathrm{m}^{-2} \cdot \mathrm{d}^{-1}$, root density increased by $72 \%$ when RZT increased from 21 to $25^{\circ} \mathrm{C}$. Root length was influenced by RZT, but not PDLI. For instance, as RZT increased from 21 to 23 or $25{ }^{\circ} \mathrm{C}$, root length increased by $30 \%$ and $20 \%$, respectively (data not shown)

Under a PDLI of $8 \mathrm{~mol} \cdot \mathrm{m}^{-2} \cdot \mathrm{d}^{-1}$, culm dry mass was higher at an RZT $\geq 23^{\circ} \mathrm{C}$. Culm dry mass increased by $39 \%$ as RZT increased from 21 to $25{ }^{\circ} \mathrm{C}$ under a PDLI of $16 \mathrm{~mol} \cdot \mathrm{m}^{-2} \cdot \mathrm{d}^{-1}$ (Table 3). Root dry mass was unaffected by the interaction between PDLI and RZT during root development. Root dry mass increased by $70 \%$ as RZT increased from 21 to $23{ }^{\circ} \mathrm{C}$ under a PDLI of $8 \mathrm{~mol} \cdot \mathrm{m}^{-2} \cdot \mathrm{d}^{-1}$, whereas under a PDLI of $16 \mathrm{~mol} \cdot \mathrm{m}^{-2} \cdot \mathrm{d}^{-1}$, root dry mass was similar among all RZT. Total dry mass increased by $97 \%$ as RZT increased from 21 to $23^{\circ} \mathrm{C}$ under a PDLI of $8 \mathrm{~mol} \cdot \mathrm{m}^{-2} \cdot \mathrm{d}^{-1}$. However, under a PDLI of $16 \mathrm{~mol} \cdot \mathrm{m}^{-2} \cdot \mathrm{d}^{-1}$, total dry mass increased by $33 \%$ as RZT increased from 21 to $25^{\circ} \mathrm{C}$ (Table 3).

Similar to Expt. 1, root-to-culm dry mass ratio, and culm and root mass ratios were significantly influenced by the main effects of PDLI and RZT (Table 3). Under both PDLIs, root-to-culm dry mass ratio exhibited a decrease with increasing RZT. For instance, root-to-culm dry mass ratio decreased from 0.10 to 0.06 when cuttings were placed under a PDLI of $8 \mathrm{~mol} \cdot \mathrm{m}^{-2} \cdot \mathrm{d}^{-1}$ with RZT increasing from 21 to $27{ }^{\circ} \mathrm{C}$ (Table 3). Under a PDLI of $16 \mathrm{~mol} \cdot \mathrm{m}^{-2} \cdot \mathrm{d}^{-1}$ and an RZT of 23,25 , and $27{ }^{\circ} \mathrm{C}$, root-to-culm dry mass ratio increased by $63 \%, 29 \%$, and $67 \%$, respectively, compared with a PDLI of $8 \mathrm{~mol} \cdot \mathrm{m}^{-2} \cdot \mathrm{d}^{-1}$. Culm mass ratio of cuttings under a PDLI of 8 and $16 \mathrm{~mol} \cdot \mathrm{m}^{-2} \cdot \mathrm{d}^{-1}$ increased by $4 \%$ and $5 \%$, respectively, as RZT increased from 21 to $27{ }^{\circ} \mathrm{C}$. Compared with culm mass ratio, an inverse trend for root mass ratio was observed under both PDLIs as root mass ratio decreased as RZT increased. For instance, root mass ratio under a PDLI of $8 \mathrm{~mol} \cdot \mathrm{m}^{-2} \cdot \mathrm{d}^{-1}$ was $40 \%$ less as RZT increased from 21 to $27{ }^{\circ} \mathrm{C}$.

\section{Discussion}

In the present study, we found rooting percentage to increase at RZT set points $\geq 23^{\circ} \mathrm{C}$ under low PDLIs of 4 or $8 \mathrm{~mol} \cdot \mathrm{m}^{-2} \cdot \mathrm{d}^{-1}$. Similar to our results, Pill and Goldberger (2010) reported rooting percentage of pinkroot [Spigelia marilandica (L.) L.] to increase by $145 \%$ when terminal cuttings were propagated at a $27{ }^{\circ} \mathrm{C}$ RZT compared with $21^{\circ} \mathrm{C}$ under ambient winter light (lat. $40^{\circ} \mathrm{N}$ ) and supplemental lighting (SL) for $16 \mathrm{~h}$. Wilkerson et al. (2005) also observed rooting percentage in poinsettia cuttings to increase from $0 \%$ to 
Table 2. (Continued) Rooting percentage, average culm number, root density (number), root length, culm dry mass, root dry mass, total dry mass, root-to-culm dry mass ratio, culm mass ratio, and root mass ratio during root development of purple fountain grass [Pennisetum $\times$ advena Wipff and Veldkamp (formerly known as Pennisetum setaceum Forsk. Chiov. 'Rubrum')] single-internode culm cuttings. During Expt. 1, cuttings were rooted for $28 \mathrm{~d}$ under $56 \%$ or $0 \%$ shade under ambient daylight supplemented with $57.6 \pm 8.1$ or $120.4 \pm 5.8 \mu \mathrm{mol} \cdot \mathrm{m}^{-2} \cdot \mathrm{s}^{-1}$, respectively, delivered from high-pressure sodium lamps from 0600 to $2200 \mathrm{HR}$ to achieve two photosynthetic propagation daily light integrals (PDLIs) of 4 and $10 \mathrm{~mol} \cdot \mathrm{m}^{-2} \cdot \mathrm{d}^{-1}$ and with root-zone temperature (RZT) set points of $21,23,25$, and $27^{\circ} \mathrm{C}$.

\begin{tabular}{lcccc}
\hline & \multicolumn{3}{c}{ RZT $\left({ }^{\circ} \mathrm{C}\right)$} \\
\cline { 2 - 5 } Photosynthetic & 21 & 23 & 25 & 27 \\
\hline Significance & $* * *$ & & \\
$\quad$ PDLI & $* * *$ & & \\
RZT & NS & & \\
PDLI $\times$ RZT & & & & \\
\hline
\end{tabular}

${ }^{\mathrm{z}}$ Rooting success (\%) of internode culm cuttings after $28 \mathrm{~d}$ under PDLI and RZT treatments.

${ }^{y}$ Within-column means followed by different lowercase letters are significantly different according to Duncan's least significant difference (LSD) test at $P \leq 0.05$.

${ }^{\mathrm{x}}$ Within-row means followed by different uppercase letters are significantly different by Duncan's LSD test at $P \leq 0.05$.

${ }_{\mathrm{NS}}, *, * *, * *$ indicate nonsignificant at $P \leq 0.05,0.01$, or 0.001 , respectively.

${ }^{\mathrm{v}}$ Number of developed culms that measured $\geq 5 \mathrm{~mm}$ in length.

${ }^{\mathrm{u}}$ Number of developed roots that measured $\geq 5 \mathrm{~mm}$ in length.

${ }^{\mathrm{t}}$ Length of the longest root that measured $\geq 5 \mathrm{~mm}$ in length.

$100 \%$ as RZT set points increased from $\approx 19$ to $29{ }^{\circ} \mathrm{C}$, respectively. Increased cellular activity at or near the severed end of the cutting base with increasing RZT leads to increased adventitious root initiation, as suggested by Pill and Goldberger (2010). Therefore, the developmental rate of adventitious root initiation is temperature- and species dependent, and subsequent development of organized adventitious root initials gives rise to adventitious root formation, thus influencing rooting of cuttings.

In Expt. 1, culm number, root density, and root length increased as PDLIs increased from 4 to $10 \mathrm{~mol} \cdot \mathrm{m}^{-2} \cdot \mathrm{d}^{-1}$ at RZT set points $\leq 25{ }^{\circ} \mathrm{C}$. Our results are in agreement with previous PDLI studies. For example, Enfield (2002) found the average number of roots per cutting of perennial garden phlox (Phlox paniculata Lyon ex Pursh 'David') to increase as PDLI increased from 0.8 to 8.6 $\mathrm{mol} \cdot \mathrm{m}^{-2} \cdot \mathrm{d}^{-1}$ at an RZT set point of $25^{\circ} \mathrm{C}$. Similarly, Lopez and Runkle (2008) reported the average root number per cutting for all New Guinea impatiens (Impatiens hawkeri Bull.) and petunia (Petunia $\times$ hybrida hort. Vilm.-Andr.) cultivars tested to increase as PDLI increased from 1.3 to $6.1 \mathrm{~mol} \cdot \mathrm{m}^{-2} \cdot \mathrm{d}^{-1}$ and 1.2 to $9.5 \mathrm{~mol} \cdot \mathrm{m}^{-2} \cdot \mathrm{d}^{-1}$, respectively, at RZT set points of 22 to $24{ }^{\circ} \mathrm{C}$. Lopez and Runkle (2008) also reported root length of all three New Guinea impatiens cultivars tested to increase as PDLI increased.

Increasing density of shoots, nodes, and roots per cutting and root length in response to increasing DLI is often a common trend among propagation and post-propagation DLI experiments. However, in Expt. 2, we found that when PDLI was reduced from 16 to $8 \mathrm{~mol} \cdot \mathrm{m}^{-2} \cdot \mathrm{d}^{-1}$ at an RZT set point of $23{ }^{\circ} \mathrm{C}$, the density of culms and roots per single-internode culm cutting increased by $98 \%$ and $67 \%$, respectively. Interestingly, we observed an inverse trend only for culm density, which increased by $65 \%$ when cuttings were placed under a PDLI of $16 \mathrm{~mol} \cdot \mathrm{m}^{-2} \cdot \mathrm{d}^{-1}$ and at an
RZT set point of $27{ }^{\circ} \mathrm{C}$, compared with a PDLI of $8 \mathrm{~mol} \cdot \mathrm{m}^{-2} \cdot \mathrm{d}^{-1}$. The observed trend of increased culm and root densities under a lower PDLI $\left(8 \mathrm{~mol} \cdot \mathrm{m}^{-2} \cdot \mathrm{d}^{-1}\right)$ than under a higher PDLI $\left(16 \mathrm{~mol} \cdot \mathrm{m}^{-2} \cdot \mathrm{d}^{-1}\right)$ in Expt. 2 has not been documented in previous PDLI experiments, but Wilkerson et al. (2005) reported a similar response for poinsettia cuttings as influenced by RZT. Martin and Ingram (1992) indicated the primary environmental factors causing changes in container substrate temperature patterns are solar radiation, wind, air temperature, and absolute air humidity. Therefore, the contrasting trends related to root density may be a result of different sensitivities to RZTs in the propagation environment caused by increased heat exchange (radiation, conduction, and convection) from the seasonal ambient solar light and SL provided by HPS lamps used to achieve the PDLIs of 8 and 16 $\mathrm{mol} \cdot \mathrm{m}^{-2} \cdot \mathrm{d}^{-1}$. This is rather unlikely as the environmental data suggest that substrate, canopy, and air temperatures, as well as RH during propagation were similar between PDLIs of 8 and $16 \mathrm{~mol} \cdot \mathrm{m}^{-2} \cdot \mathrm{d}^{-1}$ at RZT set points of 23 and $27{ }^{\circ} \mathrm{C}$. Furthermore, substrate composition has been shown to influence thermal diffusivity because of the differing thermal properties, i.e., the conductivity, bulk density, and specific heat capacity of the individual substrate components (Martin and Ingram, 1992). Rooting substrate water content can also affect thermal diffusivity (Martin and Ingram, 1992). According to the substrate physical property guidelines reported by Fonteno et al. (1995), we used a propagation substrate with high total porosity and low container capacity, air space, and bulk density. Therefore, we likely can attribute the inverse trends to solar radiation suggested by Martin and Ingram (1992).

Culm and root densities, but not root length, generally increased with increasing RZT. In Expt. 1, when cuttings were placed under PDLIs of 4 or $10 \mathrm{~mol} \cdot \mathrm{m}^{-2} \cdot \mathrm{d}^{-1}$ and RZT set points increasing from 21 to $27^{\circ} \mathrm{C}$, culm number per single-internode culm cutting increased from 3.0 to 8.4 and 4.4 to 8.6 , respectively. In addition, root density increased from 4.1 to 10.2 and 6.3 to 9.6 when cuttings were placed under PDLIs of 4 and 10 $\mathrm{mol} \cdot \mathrm{m}^{-2} \cdot \mathrm{d}^{-1}$ and RZT set points increasing from 21 to $27^{\circ} \mathrm{C}$, respectively. Similarly, for chrysanthemum cuttings, Takahashi et al. (1981) observed root density to increase as RZTs increased from 15 to $30{ }^{\circ} \mathrm{C}$. For poinsettia, Wilkerson et al. (2005) also found root density to increase from 0 to 26.8 when cuttings were propagated at RZTs from 19 to $27^{\circ} \mathrm{C}$, respectively, under a constant PDLI of $4.8 \mathrm{~mol} \cdot \mathrm{m}^{-2} \cdot \mathrm{d}^{-1}$

In Expt. 1 of our study, root length of purple fountain grass culm cuttings were shorter as RZT set points increased from 21 to $27^{\circ} \mathrm{C}$ under a PDLI of 4 or $10 \mathrm{~mol} \cdot \mathrm{m}^{-2} \cdot \mathrm{d}^{-1}$. However in Expt. 2, root length increased as RZT increased from 21 to $23{ }^{\circ} \mathrm{C}$, regardless of PDLI. Considerable evidence suggests that the rate of root extension is positively related to RZT (Pregitzer et al., 2000). For instance, Wilkerson et al. (2005) found RZTs of 26 to $28^{\circ} \mathrm{C}$ to promote the greatest root emergence and elongation in poinsettia cuttings; 31 and $33{ }^{\circ} \mathrm{C}$ to be the threshold for root emergence and elongation, respectively; and $\leq 21{ }^{\circ} \mathrm{C}$ to be the threshold where the progression toward root emergence and postemergence root growth was slow. Inconsistently, root elongation of purple fountain grass culm cuttings decreased as the $T_{\mathrm{o}}$ increased from 21 to $23{ }^{\circ} \mathrm{C}$ under PDLIs of 4 and $10 \mathrm{~mol} \cdot \mathrm{m}^{-2} \cdot \mathrm{d}^{-1}$ in Expt. 1. However, increased root elongation was observed as RZT increased up to $23{ }^{\circ} \mathrm{C}$ under a PDLI of 8 or $16 \mathrm{~mol} \cdot \mathrm{m}^{-2} \cdot \mathrm{d}^{-1}$ of Expt. 2 , therefore achieving the $T_{\mathrm{o}}$ for root growth and development.

When taking root density and length into account, cuttings under PDLIs of 4 and 10 $\mathrm{mol} \cdot \mathrm{m}^{-2} \cdot \mathrm{d}^{-1}$ at an RZT of $21{ }^{\circ} \mathrm{C}$ exhibited fewer, longer roots compared with cuttings with more, shorter roots observed at RZTs $\geq 23{ }^{\circ} \mathrm{C}$. This trend, especially under a PDLI of $10 \mathrm{~mol} \cdot \mathrm{m}^{-2} \cdot \mathrm{d}^{-1}$, influenced culm dry mass, root dry mass, and total dry mass accumulation of purple fountain grass cuttings. Previous propagation studies have indicated biomass accumulation to be positively correlated with increased PDLI (Currey et al., 2012; Enfield, 2002; Hutchinson et al., 2012; Lopez and Runkle, 2008) or RZT (Ochoa et al., 2004; Pill and Goldberger, 2010). For instance, in nine popular vegetatively propagated annual bedding plant species, Currey et al. (2012) reported shoot dry mass, root dry mass, and total dry mass to increase as PDLI increased from 1.2 to 12.3 $\mathrm{mol} \cdot \mathrm{m}^{-2} \cdot \mathrm{d}^{-1}$. Ochoa et al. (2004) reported root dry mass of oleander (Nerium oleander L.) cuttings propagated under a mean $P P F$ of 85 $\mu \mathrm{mol} \cdot \mathrm{m}^{-2} \cdot \mathrm{s}^{-1}$ to increase as RZTs increased from 18 to $25{ }^{\circ} \mathrm{C}$ and to decline at RZT $\geq 32{ }^{\circ} \mathrm{C}$, thereby slowing root growth. However, shoot dry mass of oleander cuttings increased as RZT increased from 18 to $32^{\circ} \mathrm{C}$. They concluded that RZTs $\geq 32{ }^{\circ} \mathrm{C}\left(T_{\max }\right)$ slowed root growth, thus resulting in less root dry mass. In our 
Table 3. Rooting percentage, average culm number, root density (number), root length, culm dry mass, root dry mass, total dry mass, root-to-culm dry mass ratio, culm mass ratio, and root mass ratio during root development of purple fountain grass [Pennisetum $\times$ advena Wipff and Veldkamp (formerly known as Pennisetum setaceum Forsk. Chiov. 'Rubrum')] single-node culm cuttings. During Expt. 2, cuttings were rooted for $28 \mathrm{~d}$ under $30 \%$ or $0 \%$ shade under ambient daylight supplemented with $88.3 \pm 5.3$ or $121.2 \pm 4.7 \mu \mathrm{mol} \cdot \mathrm{m}^{-2} \cdot \mathrm{s}^{-1}$, respectively, delivered from high-pressure sodium lamps from 0600 to 2200 HR to achieve two photosynthetic propagation daily light integrals (PDLIs) of 8 and $16 \mathrm{~mol} \cdot \mathrm{m}^{-2} \cdot \mathrm{d}^{-1}$ and with root-zone temperature (RZT) set points of $21,23,25$, and $27^{\circ} \mathrm{C}$.

\begin{tabular}{|c|c|c|c|c|}
\hline \multirow[b]{2}{*}{ Photosynthetic } & \multicolumn{4}{|c|}{$\operatorname{RZT}\left({ }^{\circ} \mathrm{C}\right)$} \\
\hline & 21 & 23 & 25 & 27 \\
\hline$\overline{\text { PDLI }\left(\mathrm{mol} \cdot \mathrm{m}^{-2} \cdot \mathrm{d}^{-1}\right)}$ & \multicolumn{4}{|c|}{ Rooting percentage $(\%)^{\mathrm{z}}$} \\
\hline 8 & $45 b^{y} B^{x}$ & $90 \mathrm{aA}$ & $75 \mathrm{aA}$ & $50 \mathrm{bB}$ \\
\hline 16 & $60 \mathrm{aA}$ & $80 \mathrm{aA}$ & $75 \mathrm{aA}$ & $75 \mathrm{aA}$ \\
\hline \multicolumn{5}{|l|}{ Significance } \\
\hline PDLI & $* \mathrm{w}$ & & & \\
\hline RZT & $*$ & & & \\
\hline \multirow[t]{2}{*}{$\mathrm{PDLI} \times \mathrm{RZT}$} & NS & & & \\
\hline & \multicolumn{4}{|c|}{ Culm number ${ }^{\mathrm{v}}$} \\
\hline 8 & $2.5 \mathrm{aC}$ & $8.3 \mathrm{aAB}$ & $9.2 \mathrm{aA}$ & $5.5 \mathrm{bBC}$ \\
\hline 16 & $2.8 \mathrm{aB}$ & $4.2 \mathrm{bB}$ & $6.9 \mathrm{aA}$ & $9.1 \mathrm{aA}$ \\
\hline \multicolumn{5}{|l|}{ Significance } \\
\hline PDLI & $* * *$ & & & \\
\hline RZT & NS & & & \\
\hline \multirow[t]{2}{*}{$\mathrm{PDLI} \times \mathrm{RZT}$} & $*$ & & & \\
\hline & \multicolumn{4}{|c|}{ Root density (no.) ${ }^{\mathrm{u}}$} \\
\hline 8 & $6.2 \mathrm{aA}$ & $10.7 \mathrm{aA}$ & $9.9 \mathrm{aA}$ & $7.7 \mathrm{aA}$ \\
\hline 16 & $5.8 \mathrm{aC}$ & $6.4 \mathrm{bBC}$ & $10.0 \mathrm{aAB}$ & $11.2 \mathrm{aA}$ \\
\hline \multicolumn{5}{|l|}{ Significance } \\
\hline PDLI & NS & & & \\
\hline RZT & NS & & & \\
\hline \multirow[t]{2}{*}{$\mathrm{PDLI} \times \mathrm{RZT}$} & $*$ & & & \\
\hline & \multicolumn{4}{|c|}{ Root length $(\mathrm{cm})^{\mathrm{t}}$} \\
\hline 8 & $18.1 \mathrm{aB}$ & $24.1 \mathrm{aA}$ & $24.9 \mathrm{aA}$ & $21.7 \mathrm{aAB}$ \\
\hline 16 & $21.4 \mathrm{aB}$ & $27.8 \mathrm{aA}$ & $23.0 \mathrm{aAB}$ & $24.1 \mathrm{aAB}$ \\
\hline \multicolumn{5}{|l|}{ Significance } \\
\hline PDLI & NS & & & \\
\hline RZT & $*$ & & & \\
\hline $\mathrm{PDLI} \times \mathrm{RZT}$ & NS & & & \\
\hline & & Culn & ss (mg) & \\
\hline 8 & $532 \mathrm{aC}$ & $1064 \mathrm{aA}$ & $820 \mathrm{aB}$ & $728 \mathrm{aB}$ \\
\hline 16 & $497 \mathrm{aC}$ & $642 \mathrm{bBC}$ & $693 \mathrm{aAB}$ & $821 \mathrm{aA}$ \\
\hline Significance & & & & \\
\hline PDLI & $* *$ & & & \\
\hline RZT & $* * *$ & & & \\
\hline $\mathrm{PDLI} \times \mathrm{RZT}$ & $* *$ & & & \\
\hline & & Root & $\mathrm{s}(\mathrm{mg})$ & \\
\hline 8 & $57 \mathrm{aB}$ & $97 \mathrm{aA}$ & $63 \mathrm{aB}$ & $48 \mathrm{bB}$ \\
\hline 16 & $78 \mathrm{aA}$ & $95 \mathrm{aA}$ & $69 \mathrm{aA}$ & $94 \mathrm{aA}$ \\
\hline Significance & & & & \\
\hline PDLI & $*$ & & & \\
\hline RZT & $*$ & & & \\
\hline $\mathrm{PDLI} \times \mathrm{RZT}$ & NS & & & \\
\hline & & Total $\mathrm{pl}$ & nass (mg) & \\
\hline 8 & $589 \mathrm{aC}$ & $1161 \mathrm{aA}$ & $883 \mathrm{aB}$ & $776 \mathrm{aBC}$ \\
\hline 16 & $575 \mathrm{aC}$ & $719 \mathrm{bBC}$ & $762 \mathrm{aB}$ & $915 \mathrm{aA}$ \\
\hline Significance & & & & \\
\hline PDLI & $* * *$ & & & \\
\hline RZT & $*$ & & & \\
\hline $\mathrm{PDLI} \times \mathrm{RZT}$ & $* * *$ & & & \\
\hline & & Root-to- & mass ratio & \\
\hline 8 & $0.10 \mathrm{aA}$ & $0.08 \mathrm{bA}$ & $0.07 \mathrm{bAB}$ & $0.06 \mathrm{bB}$ \\
\hline 16 & $0.14 \mathrm{aA}$ & $0.13 \mathrm{aA}$ & $0.09 \mathrm{aAB}$ & $0.10 \mathrm{aB}$ \\
\hline Significance & & & & \\
\hline PDLI & $* * *$ & & & \\
\hline RZT & $* *$ & & & \\
\hline $\mathrm{PDLI} \times \mathrm{RZT}$ & NS & & & \\
\hline & & $\mathrm{Cu}$ & ratio & \\
\hline 8 & $0.90 \mathrm{aB}$ & $0.92 \mathrm{aAB}$ & $0.93 \mathrm{aAB}$ & $0.94 \mathrm{aA}$ \\
\hline 16 & $0.86 \mathrm{aB}$ & $0.87 \mathrm{bB}$ & $0.91 \mathrm{aA}$ & $0.90 \mathrm{bAB}$ \\
\hline Significance & & & & \\
\hline PDLI & $* * *$ & & & \\
\hline RZT & $* *$ & & & \\
\hline $\mathrm{PDLI} \times \mathrm{RZT}$ & NS & & & \\
\hline & & & ratio & \\
\hline 8 & $0.10 \mathrm{aA}$ & $0.08 \mathrm{bAB}$ & $0.07 \mathrm{aAB}$ & $0.06 \mathrm{bB}$ \\
\hline 16 & $0.14 \mathrm{aA}$ & $0.13 \mathrm{aA}$ & $0.09 \mathrm{aB}$ & $0.10 \mathrm{aAB}$ \\
\hline
\end{tabular}

(Continued on next page) study, culm dry mass, root dry mass, and total dry mass varied, but were generally similar or greater at each RZT under PDLIs of 8,10 , and $16 \mathrm{~mol} \cdot \mathrm{m}^{-2} \cdot \mathrm{d}^{-1}$ compared with a PDLI of $4 \mathrm{~mol} \cdot \mathrm{m}^{-2} \cdot \mathrm{d}^{-1}$. We did observe the largest total dry mass when purple fountain grass cuttings were propagated under a PDLI of 8 $\mathrm{mol} \cdot \mathrm{m}^{-2} \cdot \mathrm{d}^{-1}$ at an RZT of $23{ }^{\circ} \mathrm{C}$. The observed total dry mass may attribute to larger root dry mass as it relates to increased root density, thereby influencing cutting nutrient uptake and use of carbohydrates for culm growth and development, thus increasing culm dry mass. Furthermore, purple fountain grass uses the $\mathrm{C}_{4}$ photosynthetic pathway (William and Black, 1993) and may benefit from warmer temperatures for root and culm initiation, development, and growth, and thus, influences biomass accumulation.

For a rooted cutting to be considered saleable, it must have a large enough root mass so that the liner may be easily removed from the propagation tray (Lopez and Runkle, 2008). Although higher overall biomass for young plants is generally desirable, assessing biomass partitioning into shoot and root growth is an important consideration for seedlings and rooted cuttings because luxurious shoot growth at the expense of root growth is not desirable in transplant production (Currey et al., 2012). We observed that when root dry mass and culm dry mass were taken together, the root-to-culm dry mass ratio increased as PDLI increased from 4 to $10 \mathrm{~mol} \cdot \mathrm{m}^{-2} \cdot \mathrm{d}^{-1}$ or from 8 to $16 \mathrm{~mol} \cdot \mathrm{m}^{-2} \cdot \mathrm{d}^{-1}$ (data not shown). Currey et al. (2012) and Lopez and Runkle (2008) reported a similar trend for all vegetative cuttings propagated under increasing PDLIs. Therefore, it appears that increasing PDLI during propagation of cuttings not only increased shoot and root growth, but partitioning of biomass into roots (Currey et al., 2012). However, root-to-culm dry mass ratio did decrease as RZT set points increased from 23 to $27^{\circ} \mathrm{C}$ under PDLIs of 8, 10 , and $16 \mathrm{~mol} \cdot \mathrm{m}^{-2} \cdot \mathrm{d}^{-1}$. It is suggested that cuttings under PDLIs of 8,10 , or $16 \mathrm{~mol} \cdot \mathrm{m}^{-2} \cdot \mathrm{d}^{-1}$ were using carbohydrate reserves for culm growth rather than partitioning and allocating for root growth, thus limiting root growth and resulting in lower root-to-culm dry mass ratios. This is evident as culm and root mass ratios display inverse trends; as RZTs increased from 21 to $27{ }^{\circ} \mathrm{C}$, culm mass ratio increased whereas root mass ratio decreased. Inconsistently, a PDLI of $4 \mathrm{~mol} \cdot \mathrm{m}^{-2} \cdot \mathrm{d}^{-1}$ and an RZT set point of $23{ }^{\circ} \mathrm{C}$ resulted in the smallest culm mass ratio because of a smaller culm dry mass and also resulted in the greatest root-to-culm dry mass ratio and root mass ratio. Therefore, under a PDLI of $4 \mathrm{~mol} \cdot \mathrm{m}^{-2} \cdot \mathrm{d}^{-1}$, cuttings were not photosynthesizing efficiently enough to produce carbohydrates for culm growth, but rather allocating stored reserves for root development and, thus, increased root dry mass.

\section{Conclusion}

The results of the present research indicate that purple fountain grass can be successfully 
Table 3. (Continued) Rooting percentage, average culm number, root density (number), root length, culm dry mass, root dry mass, total dry mass, root-to-culm dry mass ratio, culm mass ratio, and root mass ratio during root development of purple fountain grass [Pennisetum $\times$ advena Wipff and Veldkamp (formerly known as Pennisetum setaceum Forsk. Chiov. 'Rubrum')] single-node culm cuttings. During Expt. 2, cuttings were rooted for $28 \mathrm{~d}$ under $30 \%$ or $0 \%$ shade under ambient daylight supplemented with $88.3 \pm 5.3$ or $121.2 \pm 4.7 \mu \mathrm{mol} \cdot \mathrm{m}^{-2} \cdot \mathrm{s}^{-1}$, respectively, delivered from high-pressure sodium lamps from 0600 to $2200 \mathrm{HR}$ to achieve two photosynthetic propagation daily light integrals (PDLIs) of 8 and $16 \mathrm{~mol} \cdot \mathrm{m}^{-2} \cdot \mathrm{d}^{-1}$ and with root-zone temperature (RZT) set points of $21,23,25$, and $27^{\circ} \mathrm{C}$.

\begin{tabular}{lcccc}
\hline & \multicolumn{3}{c}{ RZT $\left({ }^{\circ} \mathrm{C}\right)$} & 25 \\
\cline { 2 - 5 } Photosynthetic & 21 & 23 & & 27 \\
\hline Significance & $* * *$ & & \\
PDLI & $* *$ & & \\
RZT & NS & & \\
PDLI $\times$ RZT &
\end{tabular}

${ }^{\mathrm{z}}$ Rooting success (\%) of internode culm cuttings after $28 \mathrm{~d}$ under PDLI and RZT treatments.

${ }^{\mathrm{y}}$ Within-column means followed by different lowercase letters are significantly different by Duncan's least significant difference (LSD) test at $P \leq 0.05$.

${ }^{x}$ Within-row means followed by different uppercase letters are significantly different by Duncan's LSD test at $P \leq 0.05$.

${ }_{\mathrm{NS}}, *, * *, * * *$ indicate nonsignificant at $P \leq 0.05,0.01$, or 0.001 , respectively.

${ }^{\mathrm{v}}$ Number of developed culms that measured $\geq 5 \mathrm{~mm}$ in length.

unumber of developed roots that measured $\geq 5 \mathrm{~mm}$ in length.

${ }^{\mathrm{t}}$ Length of the longest root that measured $\geq 5 \mathrm{~mm}$ in length.

propagated from single-internode culm cuttings. It is recommended that purple fountain grass propagators provide single-internode culm cuttings with a PDLI of $8-10 \mathrm{~mol} \cdot \mathrm{m}^{-2} \cdot \mathrm{d}^{-1}$ and maintain an RZT set point of 23 to $25^{\circ} \mathrm{C}$ during rhizogenesis. It is possible to obtain uniform purple fountain grass liners in $28 \mathrm{~d}$ when using the combination of PDLIs and RZTs described here. These recommendations will allow purple fountain grass propagators to efficiently and consistently root singleinternode culm cuttings. Our results expand and provide additional evidence of how PDLI and RZT influence root and culm growth, development, and morphology of purple fountain grass single-internode culm cuttings.

\section{Literature Cited}

Bailey, L.H. 1949. Manual of cultivated plants. Macmillan Publishing Co., New York, NY.

Barnes, H. 1994. Grasses from cuttings. Comb. Proc. Intl. Plant Prop. Soc. 44:543.

Blanchard, M.G., J.A. Chong, J.E. Faust, and E.S. Runkle. 2006. Temperature and light, p. 51-60. In: J.M. Dole and J.L. Gibson (eds.). Cutting propagation: A guide to propagating and producing floriculture crops. Ball Publishing, Batavia, IL.

Corley, W.L. 1989. Propagation of ornamental grasses adapted to Georgia and US south east. Proc. Intl. Plant Prop. Soc. 39:332-337.

Cunliffe, B.A., M.H. Meyer, and P.D. Ascher. 2001. Propagation of Pennisetum setaceum 'Rubrum' from cuttings. J. Environ. Hort. 19:1-3.

Currey, C.J., V.A. Hutchinson, and R.G. Lopez. 2012. Growth, morphology, and quality of rooted cuttings of several herbaceous annual bedding plants are influenced by photosyn-
Lopez, R.G. and E.S. Runkle. 2008. Photosynthetic daily light integral during propagation influences rooting and subsequent growth and development of New Guinea impatiens and petunia. HortScience 43:2052-2059.

Martin, C.A. and D.L. Ingram. 1992. Simulation modeling of temperatures in root container media. J. Amer. Soc. Hort. Sci. 117:571-577.

Meyer, M.H. and J. Hong. 2011. Miscanthus $\times$ giganteus can be propagated from stem cuttings. J. Environ. Hort. 29:193-196.

Miao, S.L., L. Kong, B. Lorenzen, and R.R. Johnson. 1998. Versatile modes of propagation in Cladium jamaicense in the Florida Everglades. Annu. Bot. 82:285-290.

Ochoa, J., S. Banon, J.A. Fernandez, J.A. Franco, and J.J. Martinez-Sanchez. 2004. Rooting medium temperature and carbohydrates affected oleander rooting. Acta Hort. 659:239-244.

Pill, W.G. and B. Goldberger. 2010. Effect of IBA treatments, bottom heat, stock plant location, and cutting type on the rooting of Spigelia marilandica cuttings. J. Environ. Hort. 28:53-57.

Preece, J.E. 1993. Basics of propagation by cuttings-Temperature. Comb. Proc. Intl. Plant Prop. Soc.. 43:441-444.

Pregitzer, K.S., J.S. King, A.J. Burton, and S.E. Brown. 2000. Response of tree fine roots to temperature. New Phytol. 147:105-115. ment. HortScience 47:25-30.

Currey, C.J. and R.G. Lopez. 2015. Biomass accumulation and allocation, photosynthesis, and carbohydrate status of New Guinea impatiens, geranium, and petunia cuttings are affected by photosynthetic daily light integral during root development. J. Amer. Soc. Hort. Sci. 140:542-549.

Drake, R. 1999. The color encyclopedia of ornamental grasses. Timber Press, Portland, OR.

Dykeman, B. 1976. Temperature relationship in root initiation and development of cuttings. Comb. Proc. Intl. Plant Prop. Soc.. 26:201-207.

Enfield, A.L. 2002. Flower induction and cultural requirements for quick-cropping of the herbaceous perennials Veronica spicata, Phlox paniculata, Leucanthemum Xsuperbum, Achillea, Gaura lindheimeri, and Campanula. Dept. Horticulture, Michigan State Univ., East Lansing. MS Thesis.

Fonteno, W.C., C.T. Harden, and J.P. Brewster. 1995. Procedures for determining physical properties of horticultural substrates using the NC State University porometer. North Carolina State Univ., Hort. Substrates Lab., Raleigh, NC.

Gawel, N.J., C.D. Robacker, and W.L. Corley. 1990. In vitro propagation of Miscanthus sinensis. HortScience 25:1291-1293.

Geiss, G., L. Gutierrez, and C. Bellini. 2009. Adventitious root formation: New insights and perspectives. Annu. Plant Rev. 37:127-156.

Hutchinson, V.A., C.J. Currey, and R.G. Lopez. 2012. Photosynthetic daily light integral during root development influences subsequent growth and development of several herbaceous annual bedding plants. HortScience 47:856-860.

Iapichino, G. and M. Bertolino. 2009. Propagation techniques for Iberis semperflorens L. Acta Hort. 813:427-434.
Robacker, C.D. and W.L. Corley. 1992. Plant regeneration of pampas grass from immature inflorescences cultured in vitro. HortScience 27:841-843.

Simon, R.A. 1982. Propagation of ornamental grasses. Proc. Intl. Plant Prop. Soc. 32:517-521.

Simpson, C.E. and E.C. Bashaw. 1969. Cytology and reproductive characteristics in Pennisetum setaceum. Amer. J. Bot. 56:31-36.

Takahashi, K., S. Matsuda, and S. Uemoto. 1981. Studies on the herbaceous cutting propagation in Chrysanthemum morifolium. I. Influences of temperatures on the increasing rate of adventitious root. Sci. Bul. Faculty Agron. Kyushu Univ. 35:1-4.

U.S. Department of Agriculture (USDA). 2010. Census of horticultural specialties (2009). Nat. Agr. Sta. Serv., Washington, DC. 22 Mar. 2014. $<$ https://www.agcensus.usda.gov/Publications/ 2007/Online_Highlights/Census_of_Horticulture_ Specialties/ $>$.

U.S. Department of Agriculture (USDA). 2015. Agr. Sta. Serv., Washington, DC. 22 Mar. 2014. $<$ https://www.agcensus.usda.gov/Publications/ 2012/Online_Resources/Census_of_Horticulture_ Specialties/>.

Wang, S., W. Carlson, H. Gao, A. Cameron, and R.D. Heins. 1999. Cultivating purple fountain grass. Greenh. Grow. 17:58-62.

Wilkerson, E.G., R.S. Gates, S.T. Kester, and R.L. Geneve. 2005. Predicting rooting stages in poinsettia cuttings using root zone temperature-based models. J. Amer. Soc. Hort. Sci. 130:302-307.

William, D.G. and R.A. Black. 1993. Phenotypic variation in contrasting temperature environments: Growth and photosynthesis in Pennisetum setaceum from different altitudes on Hawaii. Funct. Ecol. 7:623-633. Census of horticultural specialties (2014). Natl. 